\title{
Do No Harm: A Cross-Disciplinary, Cross-Cultural Climate Ethics
}

\author{
Casey Rentmeester
}

\begin{abstract}
Anthropogenic climate change has become a hot button issue in the scientific, economic, political, and ethical sectors. While the science behind climate change is clear, responses in the economic and political realms have been unfulfilling. On the economic front, companies have marketed themselves as pioneers in the quest to go green while simultaneously engaging in environmentally destructive practices and on the political front, politicians have failed to make any significant global progress. I argue that climate change needs to be framed as an ethical issue to make serious progress towards the path to a sustainable human civilization. In an effort to motivate the urgency needed to confront climate change, I argue that climate change seriously affects human beings living here and now, and if one cares about unnecessarily harming fellow innocent living human beings, then one should care about one's own environmental impact related to climate change. Since this argument does not depend upon any specific philosophical, religious, or ethical tradition but applies regardless of one's particular background, I hope to induce genuine concern among all human beings regarding this issue.
\end{abstract}

\section{Preliminaries}

James Hansen, the most eminent climatologist in the world, states, 'Climate change is likely to be the predominant scientific, economic, political and moral issue of the $21^{\text {st }}$ century'. ${ }^{1}$ While the science behind climate change becomes clearer each year, the economic and political responses have varied. On the economic front, while many companies have made concerted efforts to go green, many others simply tout themselves as pioneers in the shift to a green economy while simultaneously engaging in environmentally-destructive behaviors. Consumers are left wondering whether the green products they purchase are truly eco-friendly or whether they are being duped into the all too familiar 'greenwashing' trap. Since the major oil and coal companies are clearly

\footnotetext{
1 James Hansen and Makiko Sato, 'Paleoclimate Implications for Human-Made Climate Change', in Climate Change: Inferences from Paleoclimate and Regional Aspects, edited by A. Berger, F. Mesinger, and D. Sijacki (New York: Springer, 2012), pp. 21-47, at p. 21.
} 
the main perpetrators of the problem but insist that they are committed to environmental sustainability, it has become difficult to trust that any corporation is truly green. ${ }^{2}$ The political front has been even more frustrating. Although the creation of the United Nations Framework Convention on Climate Change (UNFCC) in 1992 was wellintentioned, the UNFCC has yet to agree upon a worldwide treaty to stabilize greenhouse gas concentrations in the atmosphere at a sustainable level. Rather than genuine cooperation, the political front has been fraught with bureaucratic hemming and hawing that has hindered any meaningful progress. Perhaps due in part to the lack of progress on the economic and political fronts, some environmentalists have shifted their focus to the ethical dimensions of climate change. ${ }^{3}$ In recent years, two of the most important public figures on climate change, former Vice President Al Gore and Rajendra Kumar Pachauri, the Chairperson of the Intergovernmental Panel on Climate Change (IPCC), have argued that climate change is essentially an ethical or moral issue. Philosophers have worked on the ethics of climate change since the early 1990s, and the questions that have guided this research have varied as the science behind climate change has become increasingly clear. After briefly explaining the scientific, economic, and political dimensions of climate change and the ethical arguments that have been offered concerning climate change, I offer a basic, straightforward ethical argument that I think will convince any reasonable person: if you think it is wrong to unnecessarily harm innocent people through your actions, then you should care about your individual contribution to climate change.

\section{The Scientific, Economic, and Political Responses}

Although scientists have conjectured about the possibility of anthropogenic climate change as early as $1896,{ }^{4}$ the first rigorous, data-based, scientifically grounded explanation of anthropogenic climate change came from NASA scientist James Hansen in a 1988 paper in the Journal of Geophysical Research. In this article, Hansen states: 'The temperature changes [due to climate change] are sufficiently large to have major impacts on man and his environment'. ${ }^{5}$ After publishing this paper, Hansen went in front of the U.S. Senate Committee on Energy and Natural Resources in June of 1988 and explained the science behind climate change. This made international news, and the global response was to create the Intergovernmental Panel on Climate Change (IPCC), a United Nationssanctioned intergovernmental body whose aim is to explain the science behind climate change and the impacts climate change will likely have on the planet. In its first

\footnotetext{
2 If one surveys the websites of the major oil companies, one will almost invariably find a major part of their platform to be dedicated to environmental sustainability. While the major coal companies are not as prevalent on the public radar, they do try to create a green public image. Peabody Energy, which has been the top U.S. coal producer for decades, calls itself 'a global leader in sustainable mining and clean coal solutions'. Cf. www.peabodyenergy.com (accessed 2013-1218).

${ }^{3}$ Martin Schönfeld nicely chronicles the shift to framing climate change as an ethical issue in 'Introduction: Plan B: global ethics on climate change', in Global Ethics on Climate Change: The Planetary Crisis and Philosophical Alternatives, edited by Martin Schönfeld (New York: Routledge, 2013), pp. 1-8.

4 Cf. Svante Arrhenius, 'On the Influence of Carbonic Acid in the Air upon the Temperature of the Ground', Philosophical Magazine and Journal of Science 41:5 (1896), pp. 237-276.

5 James Hansen et al., 'Global Climate Changes as Forecast by Goddard Institute for Space Studies Three-Dimensional Model’, Journal of Geophysical Research 93:8 (1988), pp. 9341-9364.
} 
assessment report of 1990, the IPCC spells out what anthropogenic climate change is as follows:

For a thousand years prior to the industrial revolution the abundances of [greenhouse] gases were relatively constant. However, as the world's population increased, emissions of greenhouse gases...have increased substantially due to industrialisation and changes in agriculture and land-use. ${ }^{6}$

The increase in greenhouse gases, particularly carbon dioxide and methane, due to human practices enhance the greenhouse effect, trapping more energy in the atmosphere, which leads to climate change. In this initial assessment report, several hundred scientists from 25 countries contributed. In the recent report from 2007, there were over 2500 contributors from more than 130 countries. Here, the IPCC states that 'warming of the climate system is unequivocal' ${ }^{7}$ Given the scientific consensus regarding climate change, it is not only beyond any sort of reasonable doubt that climate change is happening but also that it is an anthropogenic phenomenon. In fact, authors in reputable scientific journals are now attributing specific extreme weather patterns to anthropogenic climate change. ${ }^{8}$ The IPCC argues that we have to massively decrease our reliance on fossil fuels if we are to usher in a sustainable future for human civilizations as we have come to know them in the 21st century. In June of 2014, the atmospheric level of carbon dioxide, the most dangerous greenhouse gas, was $401 \mathrm{ppm}$ (and it has been steadily rising each year). ${ }^{9}$ The sustainable level we must stabilize at is $350 \mathrm{ppm}$ if we want to ensure a proper energy balance in the earth's atmosphere..$^{10}$

As Dale Jamieson notes, there was a public backlash in the United States to the climate change 'doom-and-gloomers' shortly after Hansen's initial testimony before the Senate. ${ }^{11}$ Many people (in the United States, at least) simply wanted more evidence that climate change was happening. In step with the general lack of public agreement on climate change, fossil fuel companies typically did not change their business strategies and went on with business as usual. As the science became increasingly clear, however, fossil fuel companies had to address the issue. George Monbiot has shown that they responded by deliberately funding lobby groups to cast doubt on the legitimacy of the science behind climate change. He states that fossil fuel companies 'sought to distance themselves from their own campaigns, creating the impression that they were

\footnotetext{
6 Intergovernmental Panel on Climate Change, Climate Change: The IPCC Scientific Assessment, edited by J.T. Houghton et al. (Cambridge: Cambridge University Press, 1990), p. xxxvii.

7 Intergovernmental Panel on Climate Change, 'Climate Change 2007: Synthesis Report: Summary for Policymakers', Fourth Assessment Report, edited by the Core Writing Team, R.K. Pachauri and A. Reisinger (Geneva, Switzerland: IPCC, 2007), p. 2.

8 This was first done by Cynthia Rosenzweig et al. in 'Attributing physical and biological impacts to anthropogenic climate change', Nature 453, (2008) pp. 353-357, and has become increasingly common since.

9 This is based on the observations of the Mauna Loa Observatory, which can be found at CO2now.org, 'Earth's CO2 Home Page' (accessed 2014-07-09).

10 Cf. James Hansen et al., 'Target Atmospheric CO2: where should humanity aim?', Open Atmospheric Science Journal 2 (2008), pp. 217-31.

11 Cf. Dale Jamieson, 'Ethics, Public Policy, and Global Warming', Science, Technology \& Human Values 17:2 (1992), pp. 139-153.
} 
spontaneous movements of professionals or ordinary scientists'.12 The logic behind this technique is simple: if doubt can be cast on the science behind dangers of fossil fuels by entities separate from the fossil fuel companies, then people will believe that there are genuine differing opinions on whether fossil fuels are contributing to the problem of climate change. ${ }^{13}$

As it turned out, such factitious skepticism only went so far: as the reality of climate change became increasingly apparent, more and more people understood that climate change was happening. In response, the fossil fuel industry changed its basic approach. Instead of denying that climate change is happening, they decided to face the issue head-on. ${ }^{14}$ Now, the major fossil fuel industries admit that climate change is happening and they also make it an essential element of their platform that they are working towards a sustainable future. However, the bottom line is that fossil fuel corporations, like all private, market-based corporations, are motivated by profit, and the less we make limiting our greenhouse gas emissions a priority, the less the corporations themselves will take this issue seriously. ${ }^{15}$

Turning our attention to politics, it is clear that the global political response has been nothing short of disastrous. The first coherent political response happened in 1992 during the Rio Earth Summit when the UNFCC was created. Here, nations vowed to take voluntary steps to lessen their greenhouse emissions. Since there were no official sanctions on emission levels, however, this did practically nothing to solve the issue. In fact, global greenhouse gas emissions only increased. The next step came with the Kyoto Protocol of 1997 in which representatives from over 70 countries came together to set legally-binding caps on the levels of carbon emissions for each country. Although sanctions were set, countries could voluntarily opt out of the Kyoto Protocol, and the United States did just that in 2001. Recently, several other high-emitting countriesRussia, Japan, and Canada-have also opted out. We are left with representatives from countries meeting quarterly to strike a deal on curbing emissions but no global agreement has been reached as of yet. And, since the 2009 UNFCC conference in Copenhagen, which was touted as the venue in which the world would take an historic step forward, turned out to be an utter failure, environmentalists are left wondering if the

12 George Monbiot, Heat: How to Stop the Planet from Burning (Cambridge, MA: South End Press, 2007), p. 34.

13 Naomi Oreskes and Erik M. Conway provide a more recent analysis of the misinformation campaigns regarding climate change in their book Merchants of Doubt: How a Handful of Scientists Obscured the Truth on Issues from Tobacco Smoke to Global Warming (New York: Bloomsbury, 2010). Cf. pp. 186-215 especially.

14 As it turns out, many of the major fossil fuel industries still fund conservative think-tanks to spread misinformation on the human contribution to climate change. However, in their public image, they (generally) no longer deny that climate change is happening and that it is partially anthropogenic.

15 Several eco-socialists have argued that economic solutions in a capitalistic system are entirely inadequate to address the problem of climate change. Fred Magdoff and John Bellamy Foster, for instance, argue that capitalism can never allow for environmental sustainability. They state, 'A system that has only one goal, the maximization of profits, has no soul, can never have a soul [and] can never be green' in 'What Every Environmentalist Needs to Know About Capitalism', Monthly Review 61:10 (2010), pp. 1-30, at p. 20. I am not arguing that we should do away with capitalism or with economic solutions altogether, but I do think they are currently insufficient to address the issue of climate change. 
necessary shift will occur in a political climate fraught with differences that prevent good faith discussion and agreement. Earth Policy Institute President Lester Brown notes that 'since no government wants to concede too much compared with other governments, the negotiated goals for cutting carbon emissions will almost certainly be minimalist, not remotely approaching the bold cuts that are needed'.$^{16}$ Therefore, just as we cannot count on an economic response to sufficiently address the issue, we cannot count on a global political response either. ${ }^{17}$

\section{The Ethics of Climate Change}

Looking at the ethical response to climate change, we can see two distinct waves since Hansen's testimony in the late '80s. The first wave comes from environmentalists like Bill McKibben and Dale Jamieson who argue that the danger that humans inflict upon the environment through our greenhouse gas emissions is unethical due to the harm inflicted upon nature and the wild species that depend upon it. In the first book-length treatise on climate change for a general audience, McKibben states, 'the way of life of one part of the world in one half century is altering every inch and every hour of the globe'.18 The result will eventually be a world devoid of wild nature, which is simply a worse world. In an early article on the ethics of climate change, Jamieson, a trained philosopher, states: 'While our species dances with the devil, the rest of nature is held hostage. Even if we step back from the precipice, it will be too late for many or even perhaps most of the plant and animal life with which we share the planet.'19 In these early works, McKibben and Jamieson argue that we should care about our relations to other species or our relation to nature itself since not doing so is a sign of gross hubris. They support a humbler, more respectful sort of attitude that celebrates the mystery and wonder that nature has to offer rather than simply seeing the natural world as a vast array of resources to be used as we see fit.

The second wave of responses is initiated by Michael Grubb, an economist and contributor to the IPCC's second assessment report. Grubb points out that climate change does not only affect the natural world or the animal and plant species that depend on it; rather, climate change is a moral issue between two groups of people: the rich, highemitting citizens of industrialized countries and the poor, low-emitting citizens of the least developed countries. He states:

In aggregate, developing countries will suffer more than developed countries as a result of climate change, though doubtless there will be exceptions. From this perspective, the central

16 Lester Brown, Plan B 4.0: Mobilizing to Save Civilization (New York: W.W. Norton, 2009), p. xii.

17 As I argue later in the paper, I think political action can be extremely impactful in certain circumstances. As global climate change negotiations have been conducted, however, I do not believe meaningful change can be brought about solely in this sphere at this time. With appropriate ethical backing (which I aim to partially provide with this paper), political action could be more decisive and meaningful in the future.

18 Bill McKibben, The End of Nature (New York: Random House, 2006 [1989]), p. 39.

19 Jamieson, p. 147. 
ethical issue is that the greenhouse gas emissions involve the rich imposing risks upon the poorer and more vulnerable. ${ }^{20}$

Here, a new dimension of the ethics of climate change arises since Grubb focuses specifically on the impacts that climate change will have on people and not nature itself or natural species. Grubb goes on to note another dimension to the ethics of climate change that has generated perhaps the most discussion in the field of climate ethics: the intergenerational aspect to climate change. He states, 'Since climate change is such a very long-term issue, the weight placed on the welfare of future generations is of central importance, one which indeed may well override most other concerns and uncertainties' ${ }^{21}$ This has prompted philosophers to focus on questions of justice and fairness regarding the risks of climate change and the unfair burdens placed on the most vulnerable: the people in the least developed countries and future generations.

Henry Shue and Stephen Gardiner were the first philosophers to take on the issues of climate justice. Shue focuses primarily on the issue of fairness in his 1999 article, 'Global Environment and International Inequality'. Noting that citizens in developed countries have contributed far more to the enhanced greenhouse effect, have far more resources to solve the problem, and are often living beyond the means necessary for basic human flourishing while others in the least developed countries have less than is needed for a decent human life, Shue argues that developed countries are responsible for tackling climate change from basic principles of fairness. ${ }^{22}$ Essentially, their failure to do so entails a commitment to making the future lives of people in the least developed countries worse than they otherwise would be, and this is simply wrong. Stephen Gardiner takes a similar approach, but focuses mainly on the intergenerational aspect to climate change. In his 2001 paper 'The Real Tragedy of the Commons', he cited the intergenerational problem of climate change as one of the major reasons that impedes a serious response. ${ }^{23}$ The problem is that the current generation prefers to overexploit the atmosphere because it benefits immediately from this practice, but future generations are put at serious risk by this overexploitation. Since overexploitation immediately benefits the current generation, we ignore the consequences bestowed upon later ones and therefore continue to overexploit. Without a serious argument as to why we should care about people that do not exist yet, this argument holds little persuasive weight for people living today, ${ }^{24}$ which is why Gardiner rightly calls the intergenerational aspect a 'serious problem' ${ }^{25}$

Recently, as the reality of climate change has become so apparent, climate ethics has become a full-fledged field in applied ethics. Most approaches to climate ethics take

${ }^{20}$ Michael Grubb, 'Seeking fair weather: ethics and the international debate on climate change', International Affairs 71:3 (1995), pp. 463-496, at pp. 467.

21 Ibid.

22 Cf. Henry Shue, 'Global Environment and International Inequality', International Affairs 75:3

(1999), pp. 531-545. Shue makes a similar argument from fairness in 'Subsistence Emissions and Luxury Emissions', Law \& Policy 15:1 (1993), pp. 39-59.

${ }^{23}$ Cf. Stephen M. Gardiner, 'The Real Tragedy of the Commons', Philosophy E Public Affairs 30:4 (2001), pp. 387-416.

24 Cf. Derek Parfit, Reasons and Persons (Oxford: Oxford University Press, 1987), pp. 351-379.

25 Stephen M. Gardiner, 'The Pure Intergenerational Problem', Monist 86:3 (2003), pp. 481-500, at p. 485. See also Gardiner's recent book, A Perfect Moral Storm: The Ethical Tragedy of Climate Change (Oxford: Oxford University Press, 2011). 
on the issue from standard ethical theories and apply the moral principles from a particular theorist to the issue at hand. I have argued that Kant's moral philosophy is a good starting point to approach climate change from an ethical perspective; ${ }^{26}$ John Broome has used utilitarian argumentation in his analysis of the ethics of climate change, ${ }^{27}$ Terry Barker et al. have argued for a contractarian approach to the injustice of overexploiting the atmosphere utilizing the philosophy of John Rawls as their lynchpin; ${ }^{28}$ and the Journal of Agricultural and Environmental Ethics recently published a special issue on environmental virtue ethics with some articles devoted to climate change. ${ }^{29}$ Most of these articles still emphasize issues of justice between the developed countries and least developed countries and the intergenerational aspect to climate change. However, given recent evidence concerning the real impacts of climate change, it is clear that people are being affected by climate change here and now, and it doesn't take a complex ethical theory to show what is wrong with those who ignore their carbon footprint. Therefore, I urge that this theory-dependent approach to climate ethics, while well-intentioned, overcomplicates the issue. If we simply chronicle the current damage that climate change is contributing to, we can shift the focus from issues of intercontinental and intergenerational justice to the simple principle of not harming other innocent human beings unnecessarily. In this way, instead of learning about Kant's categorical imperative or Mill's utilitarian standard, we can base our ethical stance on commonsense principles of fairness. Before we turn to these principles, however, we should emphasize the damage wrought by climate change.

In his recent book, Eaarth, Bill McKibben, who is the Schumann Distinguished Scholar at Middlebury College, chronicles the effects of climate change on people living here and now. He begins by stating, 'global warming is no longer a philosophical threat, no longer a future threat, no longer a threat at all. It's our reality. We've changed the planet, changed it in large and fundamental ways'..$^{30}$ This new planet that we inhabit, which McKibben calls 'Eaarth', is one that is simply harsher than the one that we have taken for granted in the 10,000 years of human civilization. With the additional energy in the climate system that comes with climate change, we have more frequent and more extreme weather events, an increase in airborne diseases, an increase in heat waves and droughts in certain regions and an increase in floods in others, greater stress on water sources, and an increase in environmental refugees as the sea level rises and low-lying coastal regions are submerged. ${ }^{31}$ McKibben provides personal accounts of how climate change affects people living here and now, including: the president of the low-lying island of Maldives saving a billion dollars annually to relocate its population before their extremely vulnerable island goes underwater; the victims of increased drought in Brazil and the effect on the quality of life; the increase of storms in Bangladesh and new challenges of unpredictability that accompany them for Bangladeshi residents; and the increase of floods in Nepal, negatively affecting the crop yields for farmers and those

26 Casey Rentmeester, 'A Kantian Look at Climate Change', Essays in Philosophy 11:1 (2010), pp. 7686.

27 Cf. John Broome, 'The Ethics of Climate Change', Scientific American 298:6 (2008), pp. 96-102.

28 Cf. Terry Barker et al., 'Climate Change, Social Justice, and Development', Development, 51:3

(2008), pp. 317-324.

29 Cf. Journal of Agricultural and Environmental Ethics 23:1-2 (2010).

30 Bill McKibben, Eaarth: Making a Life on a Tough New Planet (New York: Henry Holt, 2010), p. xiii.

31 Cf. Intergovernmental Panel on Climate Change, Climate Change: The IPCC Scientific Assessment. 
who count on them. ${ }^{32}$ Lester Brown chronicles similar events in his book, World on the Edge, such as the devastation caused by the heat wave of Western Russia in 2010 and the destruction of homes that accompanied Pakistan's massive flood of 2010.33 Perhaps the most disastrous event of all happened in 2013 with Typhoon Haiyan, the strongest storm ever recorded on landfall, which killed over 6,000 people and left about 11 million people homeless in the Philippines. Christiana Figueres, the climate chief of the United Nations, rightly called Haiyan the 'sobering reality' of climate change. ${ }^{34}$ While some scientists have been hesitant to directly attribute Typhoon Haiyan to anthropogenic climate change, the Climate Vulnerability Monitor of 2012 listed the Asia-Pacific as 'severely vulnerable' 35 to climate events such as this. A climate change-induced planet is a more energetic planet, leading to more frequent and more severe disasters, which are especially devastating in vulnerable countries, especially the least developed ones.

The sense of urgency that accompanies the reality of the damage wrought by climate change here and now is not adequately dealt with in the academic literature on climate ethics. For instance, in his book Climate Matters, Broome states: 'The harm done by climate change is insidious. Its progress till now has been so slow that we scarcely notice it, and its biggest harms will not emerge for many decades yet'. ${ }^{36}$ While he does note that the damages of climate change are now becoming apparent, his arguments are generally still focused on our obligations to future humans. For instance, he states: 'If we continue to emit greenhouse gas profligately, the lives of future people will be much worse than they would have been if we had controlled our emissions. That is the biggest reason we have for controlling emissions; the harm we do to present people is less'. ${ }^{37}$ While it is true that the progress of climate change is slow and that its biggest harms may be decades away, it is simply not the case that our focus should be future-oriented. The problem with such an approach is that it trivializes the damage experienced by humans living here and now. McKibben and Brown have chronicled the damage to current human beings, and the increasing frequency of climate-related weather events proves that the damage is already upon us. In the scientific community, this is understood. James Hansen states unequivocally that 'the unusually great temperatures extremities' seen in various parts of the world in the summer of 2011 are 'a consequence of global

\footnotetext{
32 McKibben, Eaarth, ch. 1.

${ }^{33}$ Lester Brown, World on the Edge: How to Prevent Environmental and Economic Collapse (New York: W.W. Norton, 2011), Ch. 1.

34 This statement comes from her opening speech at the climate negotiation talks in Warsaw, Poland in November of 2013.

35 Development Assistance Research Associates (DARA), 'Climate Vulnerability Monitor: A Guide to the Cold Calculus of a Hot Planet,' 2 Ed., p. 70. Cf. http://daraint.org/climate-vulnerabilitymonitor/climate-vulnerability-monitor-2012/report/ (accessed 2013-12-

19).

36 John Broome, Climate Matters: Ethics in a Warming World (New York: W.W. Norton, 2012), p. 6. While my view differs from Broome's in this regard, claims he makes later in the book are consistent with mine. His first three points of emphasis on the ethical status of emitting greenhouse gases are especially significant: 1) The harm caused by your emissions is the result of something you do; 2) The harm we do by our emissions is serious; and 3) The harm we do is not accidental. Cf. pp. 55-56.

37 Ibid., 59.
} 
warming' ${ }^{38}$ Importantly, Hansen notes that his analysis 'is an empirical approach that avoids use of global climate models, instead using only real world data' ${ }^{39}$ In other words, without even looking to the future, we can see that climate change is affecting us. This shift in our scientific knowledge requires a shift in our ethical orientation and argumentation.

We must also note that the damage does not only affect people in the most vulnerable countries like Brazil, Bangladesh, Nepal, Russia, Pakistan, or the Philippines. Since climate change is a planetary phenomenon, no country is exempt from its consequences, which the United States has recently discovered. In the spring and summer of 2012, the United States had massive heat waves wherein literally thousands of record high temperatures across cities were shattered, wildfires raged across Colorado, the Midwest experienced intense drought, leading to devastating crop failures, and the northeast was devastated by Hurricane Sandy, whose particular strength could arguably be attributed to climate change. ${ }^{40}$ All of these phenomena are in line with the predictions that the IPCC has been making for decades. Scientists are now beginning to attribute anthropogenic climate change as a contributing factor to specific disasters. This means that if you accept the simple principle that you should not harm other innocent human beings unnecessarily-the 'Do No Harm' principle-you should care about your greenhouse gas emissions since your environmental impact will affect others negatively. Moreover, the impacts caused by these emissions are not trivial. The damages wrought by floods, droughts, hurricanes, etc., devastate lives, and your individual emissions contribute to the severity of these disasters that affect other humans on this planet right now. Since much of our economy is dependent on fossil fuels, there is probably no way no completely avoid emitting some fossil fuel emissions, which is why when we apply the 'Do No Harm' principle to our environmental footprint, it only states that one should not harm others unnecessarily. This means that one should not only be conscientious of one's contribution to greenhouse gas emissions, but also that one should avoid using them unnecessarily so as not to harm other human beings unnecessarily.

The word 'unnecessarily' is the key aspect to the 'Do No Harm' principle. To explain this, we can invoke Henry Shue's distinction between subsistence emissions and luxury emissions. ${ }^{41}$ Due to the fact that our infrastructure is heavily dependent upon fossil fuels, most (if not all) human beings living here and now must depend upon them to subsist. To this extent, such usage is necessary. When a person is relying upon fossil fuels for the purpose of luxury, such as a Sunday afternoon drive with no destination in mind for sheer enjoyment or insisting on foreign bottled water when a clean tap water is readily available, this clearly exceeds subsistence measures. These latter luxury emissions are transgressions of the 'Do No Harm' principle, while subsistence emissions, such as those used to heat one's home, for instance, are not.

We all already ascribe to the 'Do No Harm' principle in our individual lives, provided we are not psychopaths or downright evil people. What many of us do not do,

\footnotetext{
38 James Hansen et al., 'Perception of climate change', Proceedings of the National Academy of Sciences of the United States of America 109:37 (2012), p. 14726.

39 Ibid.

40 This last statement regarding Hurricane Sandy comes from Jean-Pascal van Ypersele, the vice chairman of the IPCC at the U.N. climate negotiation talks in Doha, Qatar in November of 2012.

41 Shue, 'Subsistence Emissions and Luxury Emissions', p. 56.
} 
however, is apply this principle to our lives in an environmental context. Many of us commute 30 minutes to work alone in our gas-powered cars and SUVs without thinking twice about it or set the dial of our thermostats to our habitual level of comfort without questioning the long-term consequences of this action. What is needed is a way to connect the dots of our seemingly innocuous actions to the consequences that other living humans incur because of them. This requires more moments of reflection in one's everyday life. Instead of mindlessly ascribing to the status quo in the United States, for example, and commuting individually to work downtown from one's house in the suburbs, one could take up biking: a healthier alternative with no carbon footprint accompanying it. In line with this psychological shift that one has to make, one must start to think of such things in a human-oriented context rather than merely in an environmental context. In other words, one should ask oneself, 'How is this action affecting other human beings?' instead of asking 'Is this action environmentally destructive?' The more we can link up our actions to their likely consequences to other human beings, the more likely we are to actually make steps toward environmentally sustainable living. While we are hopefully sympathetic to the climate change imagery such as a polar bear stranded on a melting ice floe, a more appropriate image to incite genuine care about the issue would be images of the victims of Typhoon Haiyan. Any excess fossil fuel emissions makes disasters such as these more severe and more frequent, and we can avoid harming others unnecessarily by not using fossil fuels more than what is necessary, which would mean avoiding luxury emissions.

We have seen such movements already in environmentalism. Take, for instance, the animal rights movement. Recently, the animal rights movement has no longer focused exclusively on the pain of animals but rather on the poor working conditions of laborers in factory farms or in industries that support factory farming such as the fast food industry. While the most recent influential book on factory farming, Fast Food Nation by Eric Schlosser, documents the sad plight of animals in this sphere, stating that 'at times animals are crowded so closely together it looks like a sea of cattle,'42 the real ethical force of the work lies in the chronicling of the destitute working conditions of the laborers in the industry, the manipulation of children in marketing campaigns, and the sheer lack of attention to health concerns in this industry, all of which one implicitly supports by purchasing products from this industry. The conclusion to Schlosser's book is that we need a 'global realization' about the realities of factory farming. ${ }^{43}$ In regard to the negative effects of climate change on fellow human beings, a similar global realization needs to occur. The more we can frame environmental issues as issues of human well-being, the more traction we will attain on the ethical front of climate change. In other words, we need to shift our narrative from 'Save the Planet,' 'Save the Polar Bears' or even 'Save Our Grandchildren' to 'Save Each Other.'

The argument provided here is simple: if you care about not harming other innocent people unnecessarily through your actions, you should care about your environmental impact regarding your contribution to climate change since climate change harms other human beings. The current disasters made worse by climate change are partially caused by human actions, and the more one relies on similar actions

42 Eric Schlosser, Fast Food Nation: The Dark Side of the All-American Meal (New York: Houghton Mifflin, 2012 [2001]), p. 150.

43 Ibid., Ch. 10. 
unnecessarily, the more one transgresses the 'Do No Harm' principle. One of the benefits of this argument is that it does not rely on any sort of controversial ethical theory to back it up. The prima facie principle that it is simply wrong to harm innocent human beings unnecessarily is a cornerstone in virtually all cultural, religious, and ethical contexts. As it is theoretically uncommitted, the 'Do No Harm' principle is efficient on a practical level. Instead of working through the details of an ethical, philosophical, or religious theory and relying on the assumptions that guide it, this principle is straightforward and commonsensical, which makes it not only simple but also appealing on a wide scale. It thereby avoids the familiar problem in ethics of getting dragged down in theoretical details when the emphasis should be on how to guide action. After all, the fundamental question is ethics is 'What should we do?' and not 'Which theory should I ascribe to?' Despite the simplicity of the argument offered and the advantages that it provides, there are potential objections that must be considered.

\section{Objections and Replies}

First, one may object by saying that literally billions of other people are also part of the problem of climate change, many of which are doing nothing to cut down on their own impact on the environment. Therefore, one's own concerted effort to cut down on one's emissions really won't matter all that much since greenhouse gas emissions will continue to rise despite my own actions. Walter Sinnott-Armstrong asks the following question to make this case: Do I have a moral obligation not to drive my gas-guzzling sport utility vehicle for fun on a beautiful Sunday afternoon? He answers thusly:

My act of driving does not...make climate change worse. Climate change would be just as bad if I did not drive...Global warming and climate change occur on such a massive scale that my individual driving makes no difference to the welfare of anyone. 44

Sinnott-Armstrong clarifies this point with the following argument from analogy:

Global warming is...like a river that is going to flood downstream because of torrential rains. I pour a quart of water into the river upstream (maybe just because I do not want to carry it). My act of pouring the quart into the river is not a cause of the flood. Analogously, my act of driving for fun is not a cause of global warming. 45

He concludes that since my individual actions are so insignificant compared to such a large-scale issue, we have no moral obligation not to perform any such eco-unfriendly action. Using John Nolt's analysis that the average American's greenhouse gas emissions cause harm to one or two people, ${ }^{46}$ Avram Hiller has argued persuasively that Sinnott-

44 Walter Sinnott-Armstrong, 'It's Not My Fault: Global Warming and Individual Moral Obligations', Perspectives on Climate Change: Science, Economics, Politics, Ethics, Vol. 5, edited by Walter Sinnott-Armstrong and Richard B. Howarth (Amsterdam: Elsevier, 2005), pp. 285-307, at p. 293.

45 Ibid., p. 291.

46 John Nolt, 'How Harmful are the Average American's Greenhouse Gas Emissions?', Ethics, Policy

$\mathcal{E}$ the Environment 14:1 (2011), pp. 3-10, at p. 9. 
Armstrong is actually mistaken in his belief that there is nothing morally wrong with Sunday drives for pleasure. In critiquing Sinnott-Armstrong's idea that one's own emissions are not causes of climate change, he states, 'if individual actions such as Sunday drives are not causes of climate change, then what does cause climate change? The cause would have to be some metaphysically odd emergent entity'. ${ }^{47}$ In other words, if individual actions have no bearing on climate change, what does? Clearly, an individual drive does not itself cause climate change, but it is certainly a contributing factor, and this contribution is significant. He states, 'one Sunday drive is...prima facie wrong to a not-insignificant extent'.48 Using data from the National Academy of Sciences, he goes on to state that 'going on a Sunday drive is the moral equivalent of ruining someone's afternoon' ${ }^{49}$ Unlike Hiller, I hesitate to ascribe a one-to-one relationship between particular acts and particular consequences, though we can use Hiller's argument to support our case since it does highlight the fact that each and every person's impact on the environment matters, and the more that a person participates in fossil fuel emissions unnecessarily, the more he or she is contributing to the problem and affecting the lives of others when he or she does not have to do so. Therefore, the line of argument based on the claim that 'my own emissions are only a trivial part of the problem' does not hold. In the realm of climate ethics, I urge that we stop thinking about our fossil fuel emissions on an individual action scale and attempt the nearly impossible task of linking up particular actions with particular consequences and instead think more broadly about our lifestyle choices and how we can avoid unnecessary emissions from fossil fuel usage. Instead of avoiding 'ruining someone's afternoon', as Hiller would have us consider, we should think more broadly at the harsher world we are condemning others to have to live in. According to the Climate Vulnerability Monitor, 'in less than 20 years climate change could cause thousands of deaths and hundreds of billions of dollars in damage due to a further aggravation of weather'. ${ }^{50}$ Thinking of statistics like this and without attempting to provide a one-to-one relationship between particular acts and particular consequences, we can simply say that if one is using fossil fuels unnecessarily, one is contributing to the problem unnecessarily, and thereby transgressing the 'Do No Harm' principle. In other words, we need to reframe the debate between Sinnott-Armstrong and Hiller from 'do my individual, particular actions actually contribute to climate change?' to 'what sorts of lifestyle practices do I participate in that harm others unnecessarily?' In this way, we avoid the notoriously difficult one-to-one linking of cause and effect and engage in thinking about this issue on a more holistic scale. ${ }^{51}$

A second objection is that issues of curbing greenhouse gases should be settled by governmental bodies, not individuals, since governments have the power to make significant changes and set us on the path towards sustainability, while individuals do not. We sometimes forget that governmental bodies, at least in democratic countries, are supposed to represent the interests of the people and are dependent on the people in

47 Avram Hiller, 'Climate Change and Individual Responsibility', The Monist 94:3 (2011), pp. pp. 349-368, at p. 349.

48 Ibid., p. 358.

49 Ibid., p. 357.

50 DARA, p. 63.

51 From a practical perspective, this shifts the argument from specifying the exact harm caused by our actions to changing our attitudes and lifestyles concerning climate change as a whole. I owe this insight to Maren Behrensen, who calls this a 'pragmatically paternalistic' perspective. 
order to get elected. James Hansen, still the most important voice when it comes to climate change, has recently argued that 'the biggest obstacle to solving global warming is the role of money in politics, the undue sway of special interests'. ${ }^{52}$ Regardless of how corrupt we think our government has become, we can still affect policies through our voices as long as democracy still exists. Bill McKibben played a huge role in convincing the Obama administration to delay the Keystone XL pipeline in 2011 through concerted grassroots efforts, proving that genuine citizen-based action can incite meaningful change. The more people begin to see this issue as not only an environmental issue, or even an issue of justice between citizens of different countries or different generations, but as a clear case wherein people are harming innocent human beings through their actions, the more citizens will make this a national issue that government officials must take seriously.

A third objection regards the difficulty in assigning moral worth to actions that are seemingly innocuous. In his early article on the ethics of climate change, Dale Jamieson argues that climate change requires a paradigm shift in our understanding of ethics since conventional ethics 'presupposes that harms and their causes are individual, that they can be readily identified, and that they are local in space and time' while acts contributing to climate change are apparently innocent but have devastating consequences that are diffuse and remote in space and time. ${ }^{53}$ Gardiner picks up on this aspect of climate change in his recent book, A Perfect Moral Storm. Here, he states:

Human-induced climate change is a severely lagged phenomenon. This is partly because some of the basic mechanisms set in motion by the greenhouse effect, such as sea level rise, take a very long time to be fully realized. But it is also because by far the most important greenhouse gas produced by human activities is carbon dioxide, and once emitted molecules of carbon dioxide can spend a surprisingly long time in the atmosphere. ${ }^{54}$

While typical ethical issues such as abortion have an easy one-to-one correlation to them (typically if I abort a fetus, I am responsible for the death of that fetus), no such correlations can be made in the realm of climate change. A molecule of carbon dioxide, for instance, can stay in the atmosphere for around 100 years or longer, 55 and therefore one's particular emissions can never be directly linked to particular disasters. This leads Sinnott-Armstrong to argue, for example, that there is no way to identify any particular victim of my wasteful driving in normal circumstances'. ${ }^{56}$ Be that as it may, we are able to do a simple calculus and say that the disasters we see today that harm people are made more frequent and more severe by anthropogenic climate change, which is caused by fossil fuel emissions, and one's own fossil fuel emissions contribute to future disasters that will similarly harm people. As Jamieson notes, this does require a shift in our understanding of ethics. However, I think that the more people start to conceive of their environmental impact in terms of its harms towards other humans and less in terms of

\footnotetext{
52 James Hansen, Storms of My Grandchildren: The Truth About the Coming Climate Catastrophe and Our Last Chance to Save Humanity (New York: Bloomsbury, 2010), p. x.

53 Jamieson, pp. 148-149.

54 Gardiner, A Perfect Moral Storm, p. 32.

55 Cf. David Archer, 'Fate of fossil fuel $\mathrm{CO}_{2}$ in geologic time', Journal of Geophysical Research 110 (2005), pp. 1-6.

56 Sinnott-Armstrong, p. 294.
} 
the environment itself, the more individuals will be able to make this step. We used to think of environmentalists as hippie tree huggers who perhaps spent too much time worrying about the rights of trees, landscapes, or polar bears when actual people were suffering. Now that our environmental destruction is actually affecting humans, any reasonable person should care about their environmental impact if they hold onto the simple principle that harming innocent humans unnecessarily is wrong. ${ }^{57}$ While this shift in consciousness is not easy to make, no one promised that being an ethical person was supposed to be easy in the first place. The fact of the matter is that every single person's carbon footprint contributes to the problem, and though it is not feasible to say that your particular emissions directly caused a disaster like Hurricane Sandy or the 2012 Midwest heat wave to occur, it is clear that you contribute to disasters such as these by overly relying on fossil fuels and ignoring your environmental impact.

A final objection comes from those who say that any meaningful shift towards a green lifestyle would simply require too drastic of a lifestyle change. Since $87 \%$ of our energy use comes in the form of fossil fuels like oil, coal, and natural gas, a shift away from a lifestyle that is heavily dependent on these sources of energy would require drastic changes. People would have to rethink their transportation methods, the dial they set their thermostats at, and even the foods they put on their plates. It would mean commuting by bike, public transport, or carpool; being a bit colder in the winter months and warmer in the summer months in one's own home; and eating less from the supermarket and more locally grown foods. There is no doubt that such changes are inconvenient and sometimes difficult to take on. However, there is evidence that engaging in such lifestyle changes can often be fulfilling as well. From a social scientific perspective, Ada Ferrer-i-Carbonell and John Gowdy have shown that 'there is a strong relationship between environmental awareness and measures of subjective well-being'. ${ }^{58}$ Riding public transportation or engaging in rideshare programs can be a hassle, but it can also lead to connections among other people that we would otherwise miss out on. Going to one's local farmer's market may mean limiting the foods one can eat at any given time of the year but knowing that you are supporting local farmers instead of transnational corporations might make up for this.

Of course, the types of lifestyle changes that each individual person can afford to make are relative, and it is up to each individual person to decide what is feasible. For instance, a person living in rural Alaska must necessarily have a greater carbon footprint than someone living in San Diego simply due to geographic reasons (heating one's home, transportation options, etc.). I suspect this is true for nearly all of us. The point is not to judge others in their quest to make environmentally sustainable changes in their individual lifestyles. Rather, the point is to recognize that one's actions that rely upon greenhouse gas emissions affect people negatively, and the more one can take steps to reduce one's environmental impact, the less one is contributing to the problem. It is virtually impossible to live an entirely fossil-fuel free lifestyle in the modern world, but it

57 I do not aim to demean those who fight for the basic rights to life of trees, landscapes, and individual species; rather, I am simply making the point that environmentalism has changed in that anyone who cares about not harming other humans unnecessarily should be environmentally conscious.

58 Ada Ferrer-i-Carbonell and John M. Gowdy, 'Environmental degradation and happiness', Ecological Economics 60:3 (2007), p. 512. 
is almost certainly possible for most of us to reduce our environmental impact through lifestyle changes, thereby reducing the harm on not only the environment, but to fellow human beings.

\section{Conclusion}

I have argued that one's individual greenhouse gas emissions clearly and seriously affect other human beings in negative, nontrivial ways and that anyone who thinks it is wrong to harm others should consider their environmental impact to be a part of their ethical identity. Although we have little progress when it comes to climate change in the realms of economics and policy, if we can simply understand the basic ethical implications of greenhouse gas emissions, and we subscribe to the principle of 'Do No Harm', we should be able to make progress in our individual lives, which will eventually infiltrate the public sector. Hopefully, the non-theoretical, cross-disciplinary, cross-cultural 'Do No Harm' principle will ignite individual concern about the issue, which will then incite changes in the economic and political sectors.

Casey Rentmeester, Finlandia University casey.rentmeester@finlandia.edu

\section{Bibliography}

Archer, David. 'Fate of fossil fuel $\mathrm{CO}_{2}$ in geologic time', Journal of Geophysical Research 110 (2005), pp. 1-6.

Arrhenius, Svante. 'On the Influence of Carbonic Acid in the Air upon the Temperature of the Ground', Philosophical Magazine and Journal of Science 41:5 (1896), pp. 237-276.

Barker, Terry, Şerban Scrieciu and David Taylor. 'Climate Change, Social Justice, and Development', Development 51:3 (2008), pp. 317-324.

Broome, John. Climate Matters: Ethics in a Warming World. New York: W.W. Norton, 2012.

Broome, John. 'The Ethics of Climate Change', Scientific American 298:6 (2008), pp. 96-102.

Brown, Lester. Plan B 4.0: Mobilizing to Save Civilization. New York: W.W. Norton, 2009.

Brown, Lester. World on the Edge: How to Prevent Environmental and Economic Collapse. New York: W.W. Norton, 2011.

CO2now.org. Online at http:/ / co2now.org (accessed 2013-09-04).

Development Assistance Research Associates (DARA). 'Climate Vulnerability Monitor: A Guide to the Cold Calculus of a Hot Planet', 2 Ed. Online at http://daraint.org/climate-vulnerability-monitor/climate-vulnerability-monitor2012/report/ (accessed 2013-12-19).

Ferrer-i-Carbonell, Ada and John M. Gowdy. 'Environmental degradation and happiness', Ecological Economics 60:3 (2007), pp. 509-516.

Gardiner, Stephen M. A Perfect Moral Storm: The Ethical Tragedy of Climate Change. Oxford: Oxford University Press, 2011.

Gardiner, Stephen M. 'The Pure Intergenerational Problem', Monist 86:3 (2003), pp. 481500. 
Gardiner, Stephen M. 'The Real Tragedy of the Commons', Philosophy \& Public Affairs 30:4 (2001), pp. 387-416.

Grubb, Michael. 'Seeking fair weather: ethics and the international debate on climate change', International Affairs 71:3 (1995), pp. 463-496.

Hansen, James. Storms of My Grandchildren: The Truth About the Coming Climate Catastrophe and Our Last Chance to Save Humanity. New York: Bloomsbury, 2010.

Hansen, James and Makiko Sato. 'Paleoclimate Implications for Human-Made Climate Change', in Climate Change: Inferences from Paleoclimate and Regional Aspects, edited by A. Berger, F. Mesinger, and D. Sijacki. Vienna: Springer, 2012, pp. 21-47.

Hansen, James, I. Fung, A. Lacis, D. Rind, S. Lebedeff, R. Ruedy, G. Russell and P. Stone. 'Global Climate Changes as Forecast by Goddard Institute for Space Studies ThreeDimensional Model', Journal of Geophysical Research 93:8 (1988), pp. 9341-9364.

Hansen, James, Makiko Sato and Reto Ruedy. 'Perception of climate change', Proceedings of the National Academy of Sciences of the United States of America 109:37 (2012), pp. 14725-14726.

Hansen, James, Makiko Sato, Pushker Kharecha, David Beerling, Robert Berner, Valerie Masson-Delmotte, Mark Pagani, Maureen Raymo, Dana L. Royer and James C. Zachos. 'Target Atmospheric CO2: where should humanity aim?', Open Atmospheric Science Journal 2 (2008), pp. 217-231.

Hiller, Avram. 'Climate Change and Individual Responsibility', The Monist 94:3 (2011), pp. 349-368.

Intergovernmental Panel on Climate Change. Climate Change: The IPCC Scientific Assessment, edited by J.T. Houghton, G.J. Jenkins and J.J. Ephraums. Cambridge: Cambridge University Press, 1990.

Intergovernmental Panel on Climate Change. 'Climate Change 2007: Synthesis Report: Summary for Policymakers'. Fourth Assessment Report, edited by the Core Writing Team, R.K. Pachauri and A. Reisinger. Geneva, Switzerland: IPCC, 2007.

Jamieson, Dale. 'Ethics, Public Policy, and Global Warming', Science, Technology \& Human Values 17:2 (1992), pp. 139-153.

Journal of Agricultural and Environmental Ethics 23:1-2 (2010).

Magdoff, Fred and John Bellamy Foster. 'What Every Environmentalist Needs to Know About Capitalism', Monthly Review 61:10 (2010), pp. 1-30.

McKibben, Bill. Eaarth: Making a Life on a Tough New Planet. New York: Henry Holt and Company, 2010.

McKibben, Bill. The End of Nature. New York: Random House, 2006 [1989].

Monbiot, George. Heat: How to Stop the Planet from Burning. Cambridge, MA: South End Press, 2007.

Nolt, John. 'How Harmful are the Average American's Greenhouse Gas Emissions?', Ethics, Policy \& the Environment 14:1 (2011), pp. 3-10.

Oreskes, Naomi and Erik M. Conway. Merchants of Doubt: How a Handful of Scientists Obscured the Truth on Issues from Tobacco Smoke to Global Warming. New York: Bloomsbury, 2010.

Parfit, Derek. Reasons and Persons. Oxford: Oxford University Press, 1987.

Peabody Energy. Online at www.peabody.com (accessed 2013-12-19).

Rentmeester, Casey. 'A Kantian Look at Climate Change', Essays in Philosophy 11:1 (2010), pp. 76-86.

Rosenzweig, Cynthia, David Karoly, Marta Vicarelli, Peter Neofotis, Qigang Wu, Gino Casassa, Annette Menzel, Terry L. Root, Nicole Estrella, Bernard Seguin, Piotr 
De Ethica. A Journal of Philosophical, Theological and Applied Ethics Vol. 1:2 (2014)

Tryjanowski, Chunzhen Liu, Samuel Rawlins and Anton Imeson. 'Attributing physical and biological impacts to anthropogenic climate change', Nature 453 (2008), pp. 353-357.

Schlosser, Eric. Fast Food Nation: The Dark Side of the All-American Meal. New York: Houghton Mifflin, 2012 [2001].

Schönfeld, Martin. 'Introduction: Plan B: global ethics on climate change', in Global Ethics on Climate Change: The Planetary Crisis and Philosophical Alternatives, edited by Martin Schönfeld. New York: Routledge, 2013, pp. 1-8.

Shue, Henry. 'Global Environment and International Inequality', International Affairs 75:3 (1999), pp. 531-545.

Shue, Henry. 'Subsistence Emissions and Luxury Emissions', Law \& Policy 15:1 (1993), pp. 39-59.

Sinnott-Armstrong, Walter. 'It's Not My Fault: Global Warming and Individual Moral Obligations', in Perspectives on Climate Change: Science, Economics, Politics, Ethics, Vol. 5, edited by Walter Sinnott-Armstrong and Richard B. Howarth. Amsterdam: Elsevier, 2005, pp. 285-307.

Publication made possible by generous support from the Swedish Research Council. 
De Ethica. A Journal of Philosophical, Theological and Applied Ethics Vol. 1:2 (2014) 